\title{
Neurocysticercosis \\ Relationship between Taenia antigen levels in CSF and MRI
}

\author{
Ronaldo Abraham¹', José Antonio Livramento², Cláudia da Costa Leite³, \\ Alessandra Xavier Pardini ${ }^{4}$, Adelaide José Vaz ${ }^{4}$, Luís dos Ramos Machado ${ }^{2}$
}

\begin{abstract}
Objective: To determine the relationship between Taenia antigen (TA) detection in cerebrospinal fluid (CSF) and magnetic resonance imaging (MRI) findings in patients with definite diagnosis of neurocysticercosis (NC). Method: Sixty-three patients with definite diagnosis of NC were submitted to a MRI of the brain, and to a CSF examination, with a meticulous search for TA by ELISA. Results: TA detection was positive in 36 patients (57.1\%). A total of 836 lesions were analyzed, greatly within the cerebral parenchyma (98.7 of the lesions). Intact or non-degenerating cysts were the most common evolutive phase observed (50.4\% of all lesions), $22.1 \%$ were degenerating cysts and $19.5 \%$ calcified cysts. We observed a significant relationship between TA levels detected and the total number of lesions and the number of non-degenerating cysts, but not with calcified lesions. Conclusion: According to our results, we propose at least four important types of contribution: (1) TA detection may allow etiologic diagnosis in transitional phases of NC, with non-characteristic images; (2) in final stages of evolution of cysticercoids in the CNS, lesions may not appear on CT or MRI, and TA detection may contribute to a definite etiologic diagnosis; (3) TA detection may permit diagnosis of NC in some patients with previous negative tests for antibody detection in CSF; (4) TA detection may represent an accurate marker of disease activity in the epileptic form of NC. Key words: central nervous system, cerebrospinal fluid, enzyme-linked immunosorbent assay, magnetic resonance imaging, neurocysticercosis, Taenia antigens detection.
\end{abstract}

\section{Neurocisticercose: relação entre antígeno da Taenia no líquido cefalorraquidiano e ressonância magnética}

\section{RESUMO}

Objetivo: Determinar a relação entre a detecção de antígeno de Taenia (TA) no líquido cefalorraquidiano (LCR) e achados de ressonância magnética (RM) em pacientes com diagnóstico definitivo de neurocisticersose. Método: Sessenta e três pacientes com diagnóstico de NC foram submetidos a exame de RM e exame de LCR com pesquisa de antígeno de Taenia por método imunoenzimático. Resultados: A detecção de TA foi positiva em 36 pacientes (57,1\%). Um total de 836 lesões foram analizadas sendo 98,7\% intraparemquimatosas, 50,4\% dos cistos encontravam-se íntegros, 22,1\% degenerados e $19,5 \%$ calcificados. Foi observada relação significativa entre a presença dos níveis de TA detectados com o número total dos cistos e também com o número de cistos íntegros. Não foi observada relação com cistos calcificados. Conclusão: (1) a detecção de TA permite o diagnóstico etiológico em formas transicionais na NC com imagem pouco característica; (2) em estágio evolutivo final de um cisticerco no sistema nervoso, este pode não aparecer na tomografia computadorizada ou RM sendo a presença do antígeno importante para confirmação diagnóstica; (3) a detecção do TA permite também o diagnóstico de NC nos

Correspondence Ronaldo Abraham Rua do Bosque, 190 12093-260 Taubaté SP - Brasil E-mail: rnabraham@uol.com.br

Received 10 July 2009 Received in final form 13 September 2009 Accepted 18 October 2009 casos em que as reações inumológicas são negativas; (4) a detecção do TA representa um marcador de atividade da doença nas formas epiléticas da NC.

Palavras-chave: líquido cefalorraquidiano, detecção de antígeno de Taenia, ressonância magnética, neurocisticercose, ELISA.

${ }^{1}$ Medicine Department, University of Taubaté, Taubaté SP, Brazil; ${ }^{2}$ Neurology Department, São Paulo University Medical School (FMUSP), São Paulo SP, Brazil; ${ }^{3}$ Radiology Department, FMUSP; ${ }^{4}$ Immunology Department, São Paulo University Biomedical Science Institute of, São Paulo SP, Brazil. 
Neurocysticercosis (NC) is the most common parasitic infection of the central nervous system $(\mathrm{CNS})^{1,2}$. $\mathrm{NC}$ is caused by Cysticercus cellulosae, the larval stage of Taenia solium. Despite being a well-known disease and considered eradicable ${ }^{3-5}, \mathrm{NC}$ remains a serious public health problem in developing countries ${ }^{6}$ and represents an emerging challenge in the United States of America ${ }^{7,8}$ and some European countries ${ }^{9-12}$. In Brazil, NC is endemic $^{1}$ but is more frequently reported in the Southern, South Eastern and Central Western regions ${ }^{13,14}$. NC can manifest with a wide range of neurological symptoms, especially epilepsy ${ }^{15,16}$. Clinical manifestations correlate strongly with the phase of cysticercus biological evolution and occur mainly in the phase of impairment of parasite vitality that causes disruption of host-parasite equilibrium. This leads to perilesional inflammatory reaction, antibody-antigen interaction and immunecomplex precipitation ${ }^{17}$. Although clinical symptoms occur mainly during this phase, $\mathrm{NC}$ may be symptomatic even when the parasite calcifies and reaches the so-called inactive phase ${ }^{18}$. $\mathrm{NC}$ diagnosis is supported by clinical and epidemiological data, neuroimaging findings and specific CSF immunological reactions ${ }^{19}$.

Neuroimaging, particularly magnetic resonance image (MRI), enables recognition of the parasite at its different stages. The identification of vesicles with scolex in the brain is said to be pathognomic of NC confirming definite diagnosis, while perilesional inflammatory changes indicate parasite degenerative processes ${ }^{20-22}$. Data obtained from cerebrospinal fluid (CSF), including immunological tests based on antibody detection, are valuable and have been used for many decades to diagnose $\mathrm{NC}^{23,24}$. Taenia antigen (TA) detection using the ELISA technique ${ }^{25-28}$, is a more recent method that can provide additional information in NC diagnosis. Moreover, TA detection allows recognition of $\mathrm{NC}$ clinical activity and may be useful in the follow-up of these patients ${ }^{29-31}$.

The purpose of this study was to compare TA detected in CSF with MRI findings in NC.

\section{METHOD}

Between July 2002 and November 2005, sixty-three patients with definitive diagnosis of neurocysticercosis according to Del Brutto et al. consensus diagnostic criteria ${ }^{19}$ were evaluated. Patients from the Outpatient Clinic of Infectious Diseases of the Neurological Division of Clinicas Hospital of the São Paulo University Medical School, and from the Outpatient Neurological Clinic of the Hospital of Taubaté, University of Taubaté, were included. This study was developed according to ethics guidelines for research on human beings and was submitted for analysis and approval by the Ethics Committee for Research Analysis of the Hospitals involved. All patients included in the study signed an informed consent form.
Concerning age, 15 patients (23.8\%) were between 21 and 30 years old; 22 patients (34.9\%) between 31 and 40 years old and 19 patients (30.2\%) between 41 and 50 years old. Six patients (9.5\%) were older than 51 years, and only one was younger than 20 years old. The mean age was 37.9 years old, with no significant difference between genders. Thirty-nine patients (61.9\%) were male. Fifteen patients $(23.8 \%)$ were treated with parasiticides, five of them with repeated courses, and 58 patients with anti-inflammatory drugs (dexamethasone or dexclorpheniramine).

Epileptic seizure was the most common clinical manifestation (95.2\%). Partial seizures were more frequent than generalized episodes, partial seizures with motor symptoms proving the most common, while those with secondary generalization occurred in one third of the patients. Patients with raised intracranial pressure were excluded a priori because of the potential hazard of a lumbar puncture; however, 4 of these patients were later included after successful treatment. Besides epilepsy, the patients presented a wide variety of other associated symptoms (Table 1 ).

MRI of the brain using 1.5 Tesla equipment was performed in all patients. Images were selected from axial and coronal T2-weighted FLAIR axial images, and enhanced axial T1-weighted sequence. Total number of lesions, their location (hemispheric, superficial or deep, intraventricular, posterior fossa) and the phase of evolution of cysticerci (vesicular with or without scolex, transitional, calcification with or without enhancement) were evaluated.

All patients included in this study were submitted to a lumbar puncture for CSF analysis. This CSF sample was used to carry out: (a) a routine CSF examination; (b) a meticulous search for TA in all patients by ELISA using polyclonal antibodies extracted from rabbit hyperimmune serum, as described by Pardini et al. ${ }^{25}$; (c) a search for anti-Taenia antibodies by ELISA, passive hemaglutination and indirect immunofluorescence tests.

Table 1. Clinical manifestations (frequency of events).

\begin{tabular}{lcc}
\hline Clinical manifestation & $\mathrm{n}$ & $\%$ \\
\hline Epilepsy & 60 & 95.2 \\
Headache & 8 & 12.7 \\
Increased intracranial pressure & 4 & 6.3 \\
Psychic manifestations & 4 & 6.3 \\
Motor deficit & 3 & 4.8 \\
Vascular involvement & 2 & 3.2 \\
Optic neuritis & 2 & 3.2 \\
Meningeal syndrome & 2 & 3.2 \\
Midbrain encephalitis & 1 & 1.6 \\
\hline
\end{tabular}

n: number of cases 
Statistical analysis included ANOVA, Pearson's correlation coefficient and chi-square tests. The significance level established was $5 \%$.

\section{RESULTS}

TA detection was positive in 36 patients (57.1\%).

A total of 836 lesions were analyzed. Of these lesions 98.7\% were located within the cerebral parenchyma (396 in the right and 421 in the left hemisphere); $89.6 \%$ were located near the convexity of cerebral hemispheres. A single lesion was detected in fifteen patients (23.8\%).

Intact or non-degenerating cysts were the most common evolutive phase observed (58.4\% of all lesions); $22.1 \%$ were degenerating cysts and $19.5 \%$, calcified cysts. Comparison between MRI findings and TA in CSF are shown in Table 2 and Table 3.

We observed a significant relationship between TA levels detected and: (a) the total number of lesions; (b) the number of non-degenerating cysts. In contrast, no linear relationship was found between: (a) the number of degenerating cysts and TA levels detected in CSF; (b) the number of calcified cysts and TA levels detected (Table 2).

\section{DISCUSSION}

Our series included only patients with definite diagnosis of NC according to criteria proposed by Del Brutto et al. ${ }^{19}$. Patients with NC but without these neuroimaging patterns were not included.

We observed a high prevalence of NC epileptic form (95.2\%). This proportion differed greatly to values found by current clinical trials, from the literature series and World Health Organization data, which point to a prevalence of between 50 and $70 \%$ of NC patients having epilepsy $^{32}$. This result probably reflects a selection bias caused by the diagnostic criteria adopted.

We observed a significant relationship between the total number of lesions detected by MRI and the concentration of TA detected where this relationship was more evident in patients with two or more lesions on MRI.
Table 2. MRI variables and associated TA levels detected: regression test.

\begin{tabular}{lcc}
\hline Variable & $\mathrm{r}$ & $\mathrm{S} / \mathrm{NS}$ \\
\hline Total number of lesions $\times$ TA & 0.36 & $\mathrm{~S}$ \\
Non-degenerating cysts $\times$ TA & 0.28 & $\mathrm{~S}$ \\
Degenerating cysts $\times$ TA & 0.17 & $\mathrm{NS}$ \\
Calcified cysts $\times$ TA & 0.22 & $\mathrm{NS}$ \\
Deeply located cysts $\times$ TA & 0.36 & $\mathrm{~S}$ \\
Superficially located cysts $\times$ TA & 0.30 & $\mathrm{~S}$ \\
\hline
\end{tabular}

MRI: magnetic resonance image; TA: Taenia antigen; r: Pearson's coefficient; S: significant value; NS: non-significant value.

However, no relationship was found between the number of degenerating cysts on MRI and the intensity of TA reaction in CSF. This is an intriguing observation which we were unable to fully explain, since degenerating cysts release the highest levels of TA. We can speculate that these antigens may form immunocomplexes with anti-Taenia specific antibodies near the surface of degenerating cysts, where inflammation is currently detected as an annular or nodular enhancement by MRI. Such fixed immunocomplexes may prevent free migration of TA to the CSF system, where they are subsequently detected by our method. This hypothesis warrants more in-depth future study.

These observations may show that MRI images and biochemical detection of TA are congruent methods with correlating quantitative results, although this relationship is unlikely to be linear or constant in all evolution phases of cysticerci.

Detection of TA in $57.1 \%$ of patients with NC may be deemed a low rate, especially in comparison to other studies using the same antigen which have reported values of over $90 \%$ for patients with $\mathrm{NC}^{22}$. This strong discrepancy probably occurred for two reasons: (a) in the cited studies, which adopted less restrictive selection criteria, either no information on CSF findings was reported or most patients had an inflammatory CSF profile, in

Table 3. MRI variables associated with TA detection: frequency study (chi-square test).

\begin{tabular}{|c|c|c|c|c|}
\hline & Positive Ag & Negative Ag & $p$ & S/NS \\
\hline More than four lesions & 27 & 7 & \multirow{2}{*}{0.0001} & \multirow{2}{*}{$S$} \\
\hline Four lesions or less & 9 & 20 & & \\
\hline Two or more degenerating cysts & 22 & 4 & \multirow{2}{*}{0.0002} & \multirow{2}{*}{$S$} \\
\hline One degenerating cyst or less & 14 & 23 & & \\
\hline Deeply located cyst present & 23 & 10 & \multirow{2}{*}{0.0347} & \multirow{2}{*}{$S$} \\
\hline Deeply located cyst absent & 13 & 17 & & \\
\hline With calcified cyst & 12 & 13 & \multirow{2}{*}{1.0} & \multirow{2}{*}{ NS } \\
\hline Without calcified cyst & 24 & 18 & & \\
\hline
\end{tabular}




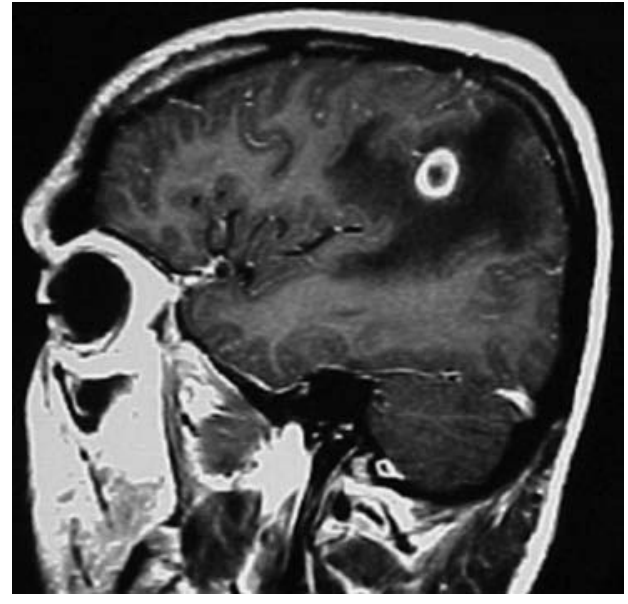

Fig 1. Case \# 56. Sagittal post-gadolinium image showing left parietal nodular lesion with anullar enhancement and massive perilesional edema.
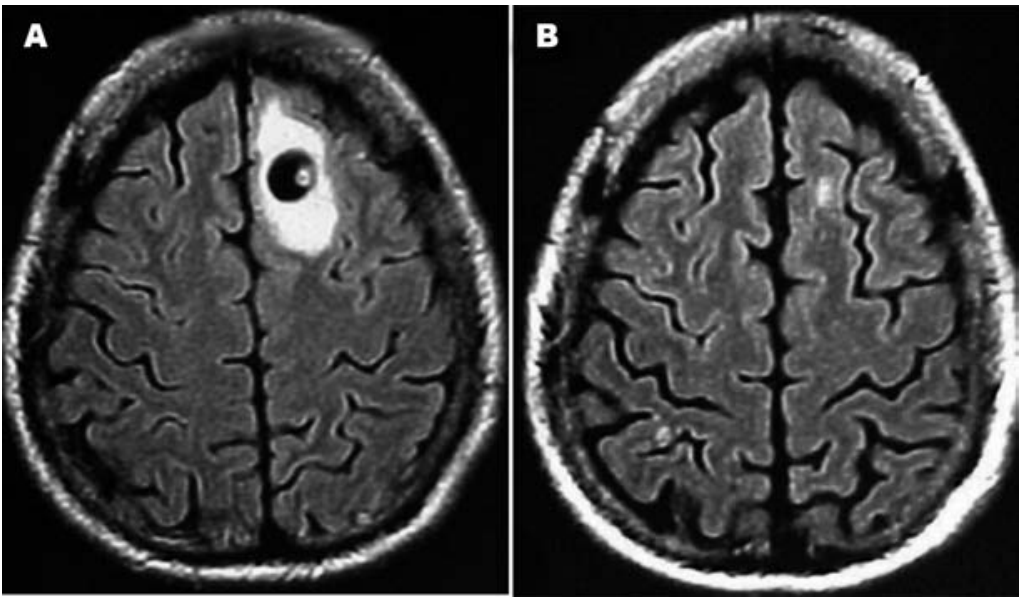

Fig 2. [A-B] Case \# 58. Axial FLAIR images obtained from the same patient, eight months apart showing lesion vanishing [B]. contrast to that observed in our series in which cell count was normal in $76.2 \%$ of patients; (b) in the present study, 98.7\% of cysticerci were cerebral parenchymal lesions, most of them (89.6\%) in hemispherical superficial areas, without contact with the CSF; (c) of the lesions detected in this study, 19.5\% were calcified residual cysticerci probably incapable of releasing antigens. Thus the sensitivity value obtained in our study was certainly underestimated for patients with NC. These low values for TA detection should be considered valid for patients with epilepsy and parenchymal forms of $\mathrm{NC}$ with little or no expression in the CSF system and which strictly meet the diagnostic criteria for $\mathrm{NC}$ of Del Brutto et al.

In the context of many diagnostic methods available for diagnosing $\mathrm{NC}$, we may rightly question what contribution can be attributed to by TA detection in CSF for NC diagnosis. We propose at least four important types of contribution, according to our results: (1) TA detection may allow etiologic diagnosis in transitional phases of NC, with non-characteristic images (Fig 1) similar to those caused by other diseases such as bacterial abscesses, tuberculous or fungic granuloma, cystic tumours, arachnoid cysts or even metastatic lesions; (2) according to Garcia et al. ${ }^{20}$, cysticerci in the CNS (Fig 2A) may not appear on CT or MRI in final stages of evolution (Fig 2B) up to 12 to 14 months. In these cases, detection of TA may contribute toward confirming a definite etiologic diagnosis, especially in cases with a single lesion and for which other methods have failed; (3) TA detection may permit diagnosis of $\mathrm{NC}$ in some patients with previous negative tests for antibody detection in CSF using several different methods (9.5\% in this study); (4) TA detection may represent an accurate marker of disease activity in the epileptic form of $\mathrm{NC}^{29}$.

In conclusion, TA detection using the method de- scribed in this study may represent a valuable aid to current CSF examination in patients with NC. This is a lowcost procedure that may dispense with more expensive investigation particularly in difficult or atypical cases.

\section{REFERENCES}

. Carpio A. Neurocysticercosis: an update. Lancet Infect Dis 2002;2:751-762.

2. Del Brutto OH. Neurocysticercosis. Sem Neurol 2005;25:243-251.

3. Garcia HH, Del Brutto OH. Neurocysticercosis: updated concepts about an old disease. Lancet Neurol 2005;4:653-661.

4. Román G, Sotelo J, Del Brutto OH, et al. A proposal to declare neurocysticercosis an international reportable disease. Bull World Health Organ 2000;78: 399-406.

5. Schantz PM, Cruz M, Sarti E, Pawlowzki Z. Potential eradicability of taeniasis and cysticercosis. Bull PAHO 1993;27:397-403.

6. Bern C, Garcia HH, Evans C, et al. Magnitude of the disease burden from neurocysticercosis in a developing country. Clin Inf Dis 1999;29:1203-1209.

7. Wallin MT, Kurtzke JF. Neurocysticercosis in the United States: review of an important emerging infection. Neurology 2004;63:1559-1564.

8. Townes JM, Hoffmann CJ, Kohn MA. Neurocysticercosis in Oregon, 19952000. Emerg Infect Dis 2004;10:508-510.

9. Esquivel A, Diaz-Otero F, Gimenez-Roldán S. Growing frequency of neurocysticercosis in Madrid (Spain). Neurologia 2005;20:116-120.

10. Imirizaldu L, Miranda L, Garcia-Gurtubay I, Gastón I, Urriza J, Quesada P. Neurocysticercosis: uma enfermedad emergente. An Sist Sanit Navar 2004;27:201-209.

11. Enseñat J, Martinez-Manas R, Horcajada JP, De Juan C, Ferrer E. Diagnostic and therapeutic difficulties in neurocysticercosis: presentation of 6 cases and review of the literature. Neurocirurgia (Astur) 2007;18:101-110.

12. Roca C, Gascón J, Font B, Pujol T, Valls ME, Corachán M. Neurocysticercosis and population movements: analysis of 23 imported cases in Spain. Eur J Clin Microbiol Infect Dis 2003;22:382-384.

13. Takayanagui OM, Leite JP. Neurocisticercose. Rev Soc Bras Med Trop 2001;34: 283-290.

14. Agapejev S. Epidemiology of neurocysticercosis in Brazil. Rev Inst Med Trop 1996:38:283-290.

15. Wittig EO. Neurocisticercose: formas clínicas e aspectos anátomo-patológicos. In Machado LR, Livramento JA, Spina-França A, Nóbrega JPS (Eds). Neuroinfecção 96; São Paulo, Clínica Neurológica HC/FMUSP; 1996:193-204

16. White AC Jr. Neurocysticercosis: a major cause of neurological disease worldwide. Clin Infect Dis 1997;24:101-115.

17. Bueno EC, Machado LR, Livramento JA, Vaz AJ. Cellular immune response of patients with neurocysticercosis (inflammatory and non-inflammatory phases). Acta Tropica 2004;91:205-213.

18. Sotelo J, Guerrero J, Rubio F. A new classification based on active and inactive forms. Arch Intern Med 1985;145:442-445. 
19. Del Brutto $\mathrm{OH}$, Rajshekhar $\mathrm{V}$, White Jr AC, et al. Proposed diagnostic criteria for neurocysticercosis. Neurology 2001;57:177-183.

20. Garcia HH, Gonzalez AE, Gilman RH. Diagnosis, treatment and control of Taenia solium cysticercosis. Curr Op Infect Dis 2003;16:411-419.

21. Dumas JL, Visy JM, Belin C, Gaston A, Goldlust D, Dumas M. Parenchymal neurocysticercosis: follow-up and staging by MRI. Neuroradiology 1997;39:12-18.

22. Amaral LLF, Ferreira RM, Rocha AJ, Ferreira NPDF. Neurocysticercosis: evaluation with advanced magnetic resonance techniques and atypical forms. Top Magn Reson Imaging 2005;16:127-144.

23. Lange O. Síndrome liquórico da cisticercose encéfalo meníngea. Rev Neurol Psiquiatr S Paulo 1940;6:35-48.

24. Spina-França A, Livramento JA, Machado LR. Cysticercosis of central nervous system and CSF: immunodiagnosis of 1573 patients in 63 years (1929-1992). Arq Neuropsiquiatr 1993;51:16-20

25. Pardini AX, Vaz AJ, Machado LR, Livramento JA. Cysticercus antigens in cerebrospinal fluid samples from patients with neurocysticercosis. J Clin Microbiol 2001;39:3368-3372.

26. Ishida MM, Peralta RH, Livramento JA, Hoshino-Shimizu S, Peralta JM, Vaz AJ. Serodiagnosis of neurocysticercosis in patients with epileptic seizure using ELISA and immunoblot assay. Rev Inst Med Trop S. Paulo 2006:48:343-346.
27. Suzuki LA, Arruda GC, Quagliato EM, Rossi QL. Evaluation of Taenia solium and Taenia crassiceps cysticercal antigens for immunodiagnosis of neurocysticercosis using ELISA on CSF samples. Rev Soc Bras Med Trop 2007;40: 152-155.

28. Mandal J, Singhi PD, Khandelwal N, Malla N. Evaluation of lower molecular mass (20-24 kDa) Taenia solium cysticercus antigen fraction by ELISA and dot blot for the serodiagnosis of neurocysticercosis in children. Parasitol Res 2008;102:1097-1101.

29. Abraham R, Pardini AX, Vaz AJ, Livramento JA, Machado LR. TA detection in the cerebrospinal fluid of patients with neurocysticercosis and its relationship with clinical activity of the disease. Arq Neuropsiquiatr 2004;62:756-760.

30. Fleury A, Hernández M, Fragoso G, Parkhouse RME, Harrison LJS, Sciutto E. Detection of secreted cysticercal antigen: a useful tool in the diagnosis of inflammatory neurocysticercosis. Royal Soc Trop Med Hyg 2003;97:542-546.

31. Bobes RJ, Hernandez M, Marquez C, et al. Subarachnoidal and intraventricular human neurocysticercosis: application of an antigen detection assay for the diagnosis and follow-up. Trop Med Int Health 2006;11:943-950.

32. Del Brutto OH, Santibañez R, Noboa CA, Aguirre R, Díaz E, Alarcón TA. Epilepsy due to neurocysticercosis: analysis of 203 patients. Neurology 1992;42: 389-392. 